\author{
Ю. В. Вороненко, О. К. Толстанов, В. В. Краснов
} Національна медична академія післядипломної освіти імені П. Л. Шупика

\title{
ЗАБЕЗПЕЧЕННЯ ЯКОСТІ У СИСТЕМІ БЕЗПЕРЕРВНОГО ПРОФЕСІЙНОГО РОЗВИТКУ ФАХІВЦІВ У СФЕРІ ОХОРОНИ ЗДОРОВ'Я
}

\author{
Y. V. Voronenko, O. K. Tolstanov, V. V. Krasnov \\ P. Shupyk National Medical Academy of Postgraduate Education \\ QUALITY ASSURANCE IN THE SYSTEM OF CONTINUOUS \\ PROFESSIONAL DEVELOPMENT OF PROFESSORS IN THE FIELD OF \\ PUBLIC HEALTH
}

\begin{abstract}
Мета роботи - охарактеризувати передумови до введення ринку освітніх послуг і забезпечення якості у системі безперервного професійного розвитку фахівців у сфері охорони здоров'я в Україні.

Основна частина. У системі безперервного професійного розвитку фахівців у сфері охорони здоров’я України створені всі передумови до введення ринку освітніх послуг із різноманіттям провайдерів державного і недержавного забезпечення. Найважливішою передумовою забезпечення якості БПР повинно бути створення єдиної системи акредитації постачальників послуг і освітніх програм, а також визначення їх (постачальників) колективної відповідальності. У НМАПО імені П. Л. Шупика проводяться основні заходи та розробляються пропозиції до моделі БПР.

Висновок. Система безперервного професійного розвитку у сфері охорони здоров'я в Україні повинна розвиватись на основі гармонізації із подібними системами у світі через закріплення на законодавчому рівні вимог до акредитації провайдерів освітніх послуг та освітніх програм.
\end{abstract}

Ключові слова: безперервний професійний розвиток; охорона здоров’я; освітня діяльність.

The aim of the work - to characterize the preconditions for the introduction of the market of educational services and quality assurance in the system of continuous professional development of specialists in the field of public health in Ukraine.

The main body. In the system of continuous professional development of healthcare professionals in Ukraine, all prerequisites for the introduction of the market of educational services with a variety of providers of state and non-state support have been created. The most important prerequisite for ensuring the quality of continuous professional development should be the creation of a unified system of accreditation of providers of educational services and programs as well as defining collective responsibility of suppliers. In the system of continuous professional development of healthcare professionals in Ukraine, all prerequisites for the introduction of the market of educational services with a variety of providers of state and non-state support have been created. P. L.Shupyk National Medical Academy of Postgraduate Education hosts major events and develops proposals for the continuous professional development model.

Conclusion. The system of continuous professional development in the health care sector in Ukraine should be developed on the basis of harmonization with similar systems of the world through the establishment of requirements for the accreditation of providers of educational services and educational programs on the legislative level.

Key words: continuous professional development; public health; educational activity.

Вступ. Забезпечення якості виконання професійних функцій фахівцями у галузі охорони здоров’я є одним з найважливіших завдань, від яких безпосередньо залежать якість життя та стан здоров'я людей, що визнаються найвищими соціальними цінностями як в Україні, так і в усьому світі. Саме тому у багатьох країнах професії у сфері охорони здоров'я мають статус регульованих, а про-

() Ю. В. Вороненко, О. К. Толстанов, В. В. Краснов ходження усіх етапів професійного навчання $€$ обов'язковим та контролюється державою.

У 2017 році поняття безперервного професійного розвитку (БПР) в Україні отримало офіційний статус. У Законі України “Про освіту” у статті 18 зазначено, що БПР - це безперервний процес навчання i вдосконалення професійних компетентностей фахівців після здобуття вищої та/або післядипломної освіти, що дає змогу фахівцю підтримувати або 
покращувати стандарти професійної діяльності і триває впродовж усього періоду його професійної діяльності [1], проте жодних рекомендацій щодо організації БПР у цьому Законі не зазначено.

Мета роботи - охарактеризувати передумови до введення ринку освітніх послуг і забезпечення якості у системі безперервного професійного розвитку фахівців у сфері охорони здоров'я в Україні.

Основна частина. Кабінет Міністрів України 28 березня 2018 року прийняв Постанову “Про затвердження Положення про систему безперервного професійного розвитку фахівців у сфері охорони здоров'я", яка регулюватиме процес БПР принаймні у сфері охорони здоров'я.

Таким чином, у системі БПР фахівців у сфері охорони здоров'я створені всі передумови до введення ринку освітніх послуг із різноманіттям провайдерів державного і недержавного забезпечення. Але цей крок до міжнародних традицій несе із собою питання забезпечення якості результатів підготовки [2].

Фахівці ВООЗ зазначають, що сьогодні в Європі не існує загальноприйнятого підходу до БПР. Проте наголошують, що велике значення має забезпечення (і підвищення) якості та вимог до академічного рівня постачальників освітніх послуг і програм навчання, на основі яких лікарі координують власні плани освітньої діяльності, тобто “...є важливим розробити єдину систему акредитації як на право проведення БПР для постачальників освітніх послуг, так і для програм навчання” [3]. Таким чином, у Європі наголошують про вкрай важливе значення контролю якості як самих провайдерів освітніх послуг, так і освітніх програм.

Той самий Закон України “Про освіту” вже ввів поняття як освітньої програми, так і можливості iї самостійного існування 3 точки зору регуляції підготовки фахівців, але залишаються відкритими питання щодо обов'язковості офіційної регуляції діяльності і провайдерів, і розроблених ними освітніх програм, які забезпечують підготовку фахівців у системі БПР.

Ми вважаємо, що найважливішою передумовою забезпечення якості БПР повинно бути створення єдиної системи акредитації постачальників послуг і освітніх програм, а також визначення їх (постачальників) колективної відповідальності.

Групою керівників систем акредитації БПР у декількох державах-членах ЄС, Сполучених Штатах Америки і Канаді розпочато підготовку концепції БПР, яка охоплює вимоги до лікарів, постачальни- ків освітніх послуг та організацій з акредитації, які засвідчують, що постачальники послуг і організатори освітньої діяльності відповідають певним стандартам акредитації. Представники організацій, що входять до системи акредитації БПР та нарахування залікових балів Болгарії, Німеччини, Іспанії, Італії, Канади, Сполученого Королівства, Сполучених Штатів Америки, Франції та ЄС, прийшли до єдиної думки про те, що впровадження систем БПР, створених на основі цієї концепції, приведе до взаємного визнання і укорінення принципу взаємності при збереженні культурної та історичної неповторності кожної системи [4].

Вже зараз у НМАПО імені П. Л. Шупика, разом з усім медичним товариством, проводяться заходи та розробляються пропозиції до моделі БПР, що включають:

- гармонізацію існуючої системи залікових кредитів України з європейськими аналогічними системами;

- розробку критеріїв акредитації провайдерів освітніх послуг, освітніх програм БПР та діяльності фахівця;

- розробку електронного портфоліо фахівця учасника БПР;

- принципи індивідуального планування фахівцем своєї діяльності з БПР;

- побудову системи та критеріїв аудиту інформальних заходів щодо підвищення кваліфікації;

- розробку критеріїв можливості включення комерційного спонсорства в планування програм навчання;

- підключення професійних асоціацій до аудиту i перевірки результатів діяльності провайдерів формальних та інформальних заходів БПР;

- побудову системи забезпечення та моніторингу якості освітньої діяльності, з забезпеченням зворотного зв’язку від учасників навчання та їх роботодавців;

- сертифікацію освітніх матеріалів;

- узгодження програм навчання з відповідними програмами деяких європейських країн тощо.

Ми вважаємо, що система БПР у сфері охорони здоров'я в Україні повинна розвиватись на основі гармонізації з подібними системами у світі через закріплення на законодавчому рівні вимог до акредитації провайдерів освітніх послуг та освітніх програм, за якими нараховуватимуться кредитні бали.

Висновки. Найважливішою передумовою забезпечення якості безперервного професійного 
розвитку повинно бути створення єдиної системи акредитації постачальників послуг і освітніх програм, а також визначення їх (постачальників) колективної відповідальності. Система безперервного професійного розвитку у сфері охорони здоров’я в
Україні повинна розвиватись на основі гармонізації із подібними системами у світі через закріплення на законодавчому рівні вимог до акредитації провайдерів освітніх послуг та освітніх програм.

\section{Список літератури}

1. Про освіту : Закон України від 05.09.2017 року № 2145-VIII. - Режим доступу : http://zakon5.rada.gov. ua/laws/show/2145-19.

2. Лінчевський О. Парламентські слухання на тему “Медична освіта в Україні: погляд у майбутнє” / О. Лінчевський. - Режим доступу : https://www.slideshare.net/ MOZukr/ss-73506506.

3. Horsley T. How to create conditions for adapting physicians skills to new needs and lifelong learning / T. Horsley, J. Grimshaw, C. Campbell // Policy Brief. - 2010; 14, WHO regional Office for Europe.

\section{References}

1. Zakon Ukrainy vid 05.09.2017 № 2145-VIII Pro vyshchu osvitu [Education Act of Ukraine № 2145-VIII of September 5, 2017]. - Retrieved from: http://zakon5.rada. gov.ua/laws/show/2145-19 [in Ukrainian].

2. Linchevskyi, O. (2017). Parlamentski sluhannia na temu: "Medychna osvita v Ukraini: pohliad u maibutne" [Parliament proceedings on a topic "Medical education in Ukraine: future outlook”]. - Retrieved from: https://www. slideshare.net/MOZukr/ss-73506506 [in Ukrainian].

3. Horsley, T., Grimshaw, J., \& Campbell, C. (2010). How to create conditions for adapting physicians skills to new needs and lifelong learning. Policy Brief 14, WHO regional Office for Europe.

4. Морозова О. М. Пошук стандартів вищої медичної освіти для вдосконалення системи охорони здоров'я / О. М. Морозова, Л. В. Батюк, В. Г. Кнігавко // Актуальні питання якості медичної освіти : матеріали XIII Всеукр. наук.-практ. конф. з міжнар. участю (з дистанційним під'єднанням ВМ(Ф)НЗ України за допомогою відеоконференц-зв’язку) (Тернопіль, 12-13 трав. 2016 року). - Тернопіль, 2016. - Т. 1. - С. 109-110.

4. Morozova, O.M., Batiuk, L.V., \& Knihavko, V.H. (2016). Poshuk standartiv vyshchoi medychnoi osvity dlia vdoskonalennia systemy okhorony zdorovia [Searching of standards in higher medical education to improve the health care system]. Aktualni pytannia yakosti medychnoi osvity: materialy XIII Vseukrainskoi naukovo-praktychnoi konferentsii z mizhnarodnoiu uchastiu (z dystantsiinym pidiednanniam VM(F)NZ Ukrainy za dopomohoiu videokonferents-zviazku), Ternopil, 12-13 travnia 2016 Current Issues of Quality of Medical Education: Materials of XIII All-Ukrainian Scientifc Conference with International Participation (with remote connectivity $\mathrm{HM}(\mathrm{Ph}) \mathrm{EI}$ of Ukraine via video-link), Ternopil May 12-13, 2016 [in Ukrainian].

Отримано 03.04.18

Електронна адреса для листування: ppmfp.nmapo@gmail.com 